\title{
Food of the House Shrew, Suncus murinus sindensis in the Indian Desert
}

\author{
POKARM SUNCUS MURINUS SINDENSIS
}

Ranjan ADVANI \& B. D. Rana

\begin{abstract}
Advani R. \& Rana B. D., 1981: Food of the house shrew, Suncus murinus sidensis in the Indian desert. Acta theriol., 26, 7: 133-134 [With 1 Table]
\end{abstract}

[Central Arid Zone Res. Inst., Jodhpur - 342003, India]

The house shrew, Suncus murinus sindensis Anderson, 1877, is fairly common in crop as well as the grassland in the Indian desert. When we found the stomachs of this insectivore full of vegetation, the contents were analysed gravimetrically (Murton et al., 1964) on the Semi-micro Mettler balance. The insectivorous were collected at Bisalpur $\left(27^{\circ} 7^{\prime} \mathrm{N}-\right.$ $\left.73^{\circ} 10^{\prime} \mathrm{E}\right), 10 \mathrm{kms}$ north of the Jawai Dam in South-eastern desert of Rajasthan during the year 1978.

On an yearly basis (Table 1), their food was composed of various parts of vegetation (90.66 per cent) and insects constituted only 8.64 per cent of the diet. Seasonally, insects were consumed in slightly higher proportion during May, June and July, the summer months when the green vegetation is not available to them.

Bisalpur, situated on the slopes of Aravalli mountains, where the study was carried out, is relatively a wet zone receiving on an average a rainfall of $500 \mathrm{~mm}$ per annum, mostly from July to September. The study area is well vegetated and there is a relative abundance of insects. It is not easy to postulate why this insectivorous mammal preferred to survive on vegetation as compared to more nutritive insect diet.

As reported by Roberts (1977) the normal food of Suncus murinus (subspecies tytleri and sindensis) is, however insects particularly crickets (Grillidae spp.) and cockroaches (Blattaria spp.) in Pakistan. He also stated that there are records that this shrew inflicts damage on garden lawns by digging out and eating the bulbils of a grass in Pakistan. Balakrishan (1977) in his laboratory studies has reported that the allied subspecies, S. $m$. viridescens preferred insects and also readily fed upon many other food items including fish, beef, molluscan meat, even rice and wheat flours. In the present study, the occurrence of vegetation all the year round is rather perplexing!

Acknowledgements: The authors are grateful to Dr. H. S. Mann, Director, Central Arid Zone Research Institute, Jodhpur for providing necessary facilities and encouragement. We are highly indebted to Dr. Ishwar Prakash, Coordinator and Principal Animal Ecologist for his painstaking guidance throughout the course of this study.

\section{REFERENCES}

Balakrishnan M., 1977: Feeding behaviour, food motivation and food utilization of the Indian musk shrew, Suncus murinus viridescens (Blyth). [In: "Neuro humoral correlates of Behaviour«, Ed. Sarada subrahmanyam]. Thomson Press (India) Ltd., Faridabad, 175-185. - Murton R. K., Westwood M. J. \& Issacson A. J., 1964: Feeding habits of the Wood pigeon; Columba palambus, Stockdove Columba oenas and Turtle dove Streptopelia turtur. Ibis, 106: 174-188. Roberts T. J., 1977: The Mammals of Pakistan. Ernest Benn Ltd.: XXVI+1-361.

Accepted, September 20, 1980. 
Table 1

Monthly distribution of gut items of Suncus murinus sindensis (text see p. 133).

\begin{tabular}{|c|c|c|c|c|c|c|c|c|c|c|c|c|c|}
\hline Food items & $\begin{array}{l}\text { Jan, } \\
(10)^{1}\end{array}$ & $\begin{array}{l}\text { Feb. } \\
(10)\end{array}$ & $\underset{(6)}{\operatorname{Mar}}$ & $\begin{array}{l}\text { Apr. } \\
(9)\end{array}$ & $\begin{array}{c}\text { May } \\
(7)\end{array}$ & $\underset{(3)}{\text { June }}$ & $\begin{array}{l}\text { July } \\
\text { (5) }\end{array}$ & Aug. & $\begin{array}{l}\text { Sept. } \\
\text { (14) }\end{array}$ & $\begin{array}{l}\text { Oct. } \\
(23)\end{array}$ & Nov. & $\begin{array}{l}\text { Dec. } \\
(14)\end{array}$ & $\begin{array}{l}\text { Annual percent } \\
\text { occurence }\end{array}$ \\
\hline Unident. vegetation & 91.5 & 75.7 & - & 85.5 & 60.3 & 60.9 & 63.3 & 92.6 & 97.7 & 72.9 & 91.3 & 96.4 & 88.6 \\
\hline Leaf blades & - & - & 67.7 & 1.7 & 3.2 & - & 4.2 & - & 0.6 & 2.1 & - & 1.2 & 1.7 \\
\hline Seeds of cucurbit & - & - & - & - & - & - & - & - & - & - & - & 0.4 & 0.0 \\
\hline Rhizomes of grasses & - & 8.8 & - & 0.2 & 3.9 & - & 0.5 & - & - & 4.2 & - & - & 0.3 \\
\hline Total vegetation & 91.5 & 83.5 & 67.7 & 87.4 & 67.4 & 60.9 & 67.9 & 92.6 & 98.4 & 79.2 & 91.3 & 98.0 & 90.7 \\
\hline Fur & 1.9 & - & 19.2 & 6.0 & - & - & 7.0 & - & - & 6.2 & 0.3 & 0.4 & 0.7 \\
\hline Insect parts ${ }^{2}$ & 6.6 & 15.5 & 13.1 & 6.7 & 32.6 & 39.1 & 25.1 & 7.4 & 1.6 & 14.6 & 8.5 & 1.6 & 8.6 \\
\hline
\end{tabular}

1 The total number of shrews captured and examined, ${ }^{2}$ Legs, antennae, terga sterna etc. of orders Coleoptera, Hymenoptera, Orthoptera (Gryllidae) and Hemiptera. 